\title{
Revisiting discourse on Islam and state relation in Indonesia: the view of Soekarno, Natsir and Nurcholish Madjid
}

\author{
Ahmad Ali Nurdin \\ Sunan Gunung Djati State Islamic University, Bandung. \\ E-mail:nurdinster@gmail.com
}

DOI: 10.18326/ijims.v6i1.63-92

\begin{abstract}
This paper focuses on debates between Soekarno, Natsir and Nurcholish Madjid to whether Indonesian state should be based on Islam ideologically or not. Soekarno, was in favor of the separation between Islam and state and against the idea of a formal-legal relationship between them. In Soekarno's belief, by separating religion from the state, it does not mean that Islamic teachings are automatically marginalized. Natsir argued against Soekarno's idea that Islam should be separated from the state. Natsir believed that Islam is a way of life in which it not only guides Muslim peoples on ritual matter but also on worldly matters including how to manage a state. Madjid seems to propose the middle path between Soekarno and Natsir in his struggle to 'Islamize' Indonesia. On the one hand, Madjid opposes the idea of making Indonesia an Islamic state, and on the other hand, Madjid also refuses that Indonesian become totally a secular state. Madjid tried to develop a new format for political Islam in which substance, rather than form, serves as his primary orientations.
\end{abstract}


Kajian ini berfokus pada perdebatan antara Soekarno, Natsir dan Nurcholish Madjid tentang apakah negara Indonesia harus didasarkan pada Islam ideologis atau tidak. Soekarno adalah pendukung pemisahan antara Islam dan negara dan menentang gagasan hubungan formal-legal antara keduanya. Dalam keyakinan Soekarno, dengan memisahkan agama dari negara, itu tidak berarti bahwa ajaran Islam secara otomatis terpinggirkan. Natsir menentang gagasan Soekarno bahwa Islam harus dipisahkan dari negara. Natsir percaya bahwa Islam adalah cara hidup yang tidak hanya membimbing masyarakat Muslim tentang masalah ritual tetapi juga pada hal-hal duniawi termasuk bagaimana mengelola negara. Madjid tampaknya mengusulkan jalan tengah antara Soekarno dan Natsir dalam perjuangan untuk 'mengislamkan' Indonesia. Di satu sisi, Madjid menentang ide menciptakan Indonesia sebagai negara Islam, dan di sisi lain, Madjid juga menolak bahwa Indonesia menjadi benar-benar sebuah negara sekuler. Madjid mencoba untuk mengembangkan format baru bagi Islam politik di mana substansi, bukan bentuk, berfungsi sebagai orientasi utamanya.

Keywords: Islamic State; Jakarta Charter; Soekarno; Natsir; Nurcholish Madjid

\section{Introduction}

The issue of Islam and state relations has become a central debate in Indonesia even since the state formation process prior to the declaration of independence in 1945. During this period the founding fathers of Indonesia were engaged in an intense debate of the basis of the state. The debate reflects deep-seated ideological and political divisions between kebangsaan groups (secular nationalists) who preferred a non-theocratic form of the state and the Islamic groups who argued for the Islamic state. ${ }^{1}$ On the one hand, the leading figures of the kebangsaan group were represented by Soekarno, Sutan Sjahrir ${ }^{2}$ and Muhammad Hatta, ${ }^{3}$ and Is-

\footnotetext{
${ }^{1}$ Rizal Sukma, Islam in Indonesian Foreign Policy, New York: Routledge Curzon, 2003, 1.

${ }^{2}$ Sutan Sjahrir (5 March 1909 - 9 April 1966) was the first prime minister of Indonesia, after a career as a key Indonesian nationalist movement figure in the 1930s and 1940s.
} 
lamic groups, on the other hand, were represented by Natsir, ${ }^{4}$ H.O.S. Cokroaminoto, ${ }^{5}$ and Abdul Moeis. Since both groups mostly consisted of

Sjahrir was born in 1909 in Padang Panjang, West Sumatra; He helped set up the Indonesian National Party (PNI), and became a close associate of future vice president Mohammad Hatta. He was imprisoned by the Dutch for nationalist activities in November 1934, first in Boven Digul, then on Banda, and then in 1941, just before the Indies fell to the Japanese, to Sukabumi. He was appointed Prime Minister by President Sukarno in November 1945 and served until June 1947. Sjahrir founded the Indonesian Socialist Party in 1948, which, although small, was very influential in the early post-independence years, because of the expertise and high education levels of its leaders. But the party performed poorly in the 1955 elections and was banned by President Sukarno in 1960. Sjahrir was jailed in the early 1960s, and died in exile in Zürich, Switzerland in 1966. See Anderson, Benedict R. O'G. Java in a Time of Revolution: Occupation and Resistance, 1944-1946, Ithaca: Cornell University Press, 1972 and also http://www.nationmaster.com/encyclopedia/Sutan-Syahrir.

${ }^{3}$ Muhammad Hatta (1902-1980), Indonesian nationalist leader and vice president. Born on 12 August 1902 in Bukittinggi, Sumatra, he studied in the Netherlands, where he obtained a doctorate in economics in 1932. Returning to Indonesia, he became active in the Indonesian nationalist movement and was arrested by the After World War II, Hatta became vice president under Sukarno of the Indonesian Republic they declared. Dutch in 1934, and was imprisoned on the island of Bandanaira. He was released by the Japanese in 1942. The Dutch resisted the nationalists, and Hatta became premier and defense minister in 1948 to direct the fight against the Dutch troops. Again imprisoned by the Dutch in 1949, Hatta was released to head a delegation to the Hague and there successfully negotiated a settlement. He was (1949-50) again prime minister before serving (1950-56) as vice president of the republic; he resigned 1956 after a dispute with Sukarno. Hatta withdrew from political life and devoted himself primarily to the cooperative movement in Indonesia. After Sukarno's fall from power, Hatta returned to government service as an adviser to President Suharto. See his Portrait of a Patriot: Selected Writings (1973) and also see http:// www.encyclopedia.com/doc/1E1-Hatta-Mo.html

${ }^{4}$ His personal details and political thought will be explained in this chapter.

${ }^{5}$ Hadji Oemar Said Tjokroaminoto popularly known as HOS Tjokroaminoto (August 16, 1882 - December 17, 1934) was a nationalist, the first leader of Sarekat Dagang Islam (Islamic Trade Union, later Sarekat Islam) in Indonesia. Born in Madiun as the son of RM. Tjokroaminoto (district chief of Kleco). When H. Samanhoedi had founded Sarekat Dagang Islam (SDI, in the late 1911). Tjokroaminoto was asked to prepare needed regulations for organization and next management handling. After that the statuten (statute) was prepared and strengthened by notarial act in Surabaya (September 10, 1912). The word Dagang (trade) in the organization's name was removed and SDI became SI (Sarekat Islam; Islamic Union). Its chairman was H. Samanhoedi, while Tjokroaminoto became commissioner Because of rapid development of local SIs, it was necessary to establish a central SI coordinating them. On 1915, the Centraal Sarekat Islam (CSI) was founded with Tjokroaminoto as its chairman, Abdoel Moeis as its vice-chairman, and Samanhoedi as honorary chair 
Muslim individuals, for Effendy, the two groups' division should be seen in the light of political categories instead of religious.

In my view, the fundamental differences between the Muslims who aspired for the development of Islam as a political category and the Muslim who favoured Islam as moral or ethical underpinning in their ideological-political ventures lay not so much on the degree of religious devotions (or faith), but on the way they interpreted and understood the messages of Islam...therefore, even having to reject the idea of an Islamic state, individuals like Soekarno and Hatta were no less Islamic than their Muslim counterparts who strived for an Islamic state. ${ }^{6}$

The same as Effendy, Anwar argues that these two different opinions in political Islam in the world, including in Indonesia was influenced by their interpretation and understanding of the message of Islam. Anwar classifies these two groups into legal exclusive and substantive-inclusive. While the former refers to the idea that Islam is not only a religion but also a complete legal system, universal ideology, and a perfect system of guidance; the former refers to the notion that Islam as a religion does not stipulate any theoretical concepts related to politics and the Quran only contains information about aspects of ethical or moral guidance for human life. Hosen called these two groups as formal and substantive shariah groups. ${ }^{8}$

man. Since then Tjokroaminoto was continuously chairman or member of SI Board of Administration until his death. When the CSI became weak, and its name was changed to PSI (Partai Sarekat Islam; Islamic Union Party) on February 1923. Later PSI was changed to PSII (Partai Syarikat Islam Indonesia, Indonesian Islamic Union Party) in early 1929. There was a confrontation between nationalist Soekiman and religious Tjokroaminoto that led to Soekiman's discharge to form a new party, Partai Islam Indonesia (Indonesian Islamic Party). See http://en.wikipedia.org/wiki/Tjokroaminoto.

${ }^{6}$ Bahtiar Effendy, Islam and the State in Indonesia, Singapore: Institute of Southeast Asian Studies, 2003, 55.

${ }^{7}$ M. Syafi'i Anwar, "Shari'a, Pluralism and the Prospect of democracy in Post Soeharto Indonesia”, paper presented at EU-Indonesia Day Conference on Pluralism and Democracy: Indonesian Perspective, Brussels, 7 December, 2006, 4-5.

${ }^{8}$ Nadirsyah Hosen, Syariah and Constitutional Reform in Indonesia (1999-2002), PhD thesis at National University of Singapore, 2005, 56. 
Based on the background above, this paper discusses debates between Soekarno and Natsir followed by discussion of Nurcholish Madjid's view to whether Indonesian state should be based on Islam ideologically and how this debate has been followed by Islamic civil society groups and political parties in the country afterward. Such debates of inclusion of the Jakarta Charter into the Indonesian constitution and the debate to whether Indonesia should be an Islamic state or state which separate religion from state affairs have colored Indonesia political history up to present.

The ideas of these three figures are important to be discussed due to several reasons. Firstly, the polemic among them reflects the ideological 'fight' between two big groups in the Indonesian history and the contents of the polemic are very fundamental and seems to be never ending debate even after Indonesian independence up to present. ${ }^{9}$ Secondly, Soekarno and Natsir could be seen as the leading political figures in the political history of Indonesia while Nurcholish could be seen as a leading Muslim intellectual who do not agree with both Natsir and Soekarno in using political party as 'a tool' to promote his idea. Soekarno, on the one hand, has significantly colored the development of political thinking in pre-independence era up to contemporary Indonesia. It suffices to say that Indonesian nationalism; more or less was based on Soekarno's political thought. Natsir, on the other hand, is very identical with Islamic political figure and has dominated Islamic political thinking in Indonesia. That is why Feith and Castle call Natsir as a 'reformist Islam':

"As an ideology addressing itself to contemporary political affairs, Indonesian Islam has been dominated by the ideas of the reformists,

\footnotetext{
${ }^{9}$ It can be seen from the fact that even after Soeharto's period, there are debates among Muslims to include the Islamic sharia into Indonesian constitution.
} 
and reformism has been typified by the thinking of the former Masjumi chairman, Mohammad Natsir". ${ }^{10}$

\section{Soekarno: Islam and state should be separated}

The polemic between Soekarno and Natsir on Islam and state relationship were begun when Soekarno wrote his article entitled 'Apa Sebab Turki Memisah Agama dari Negara"? (Why has Turkey Separated Religion from the State?) in Pandji Islam magazine in 1940. ${ }^{11}$ As claimed by Soekarno, this article was written by him as his answer to accommodate the readers of the magazine who requested him to write more on Islamic issues particularly after Soekarno's writing entitled "Memudakan Pengertian Islam" (Rejuvenating our Concepts of Islam) in the same magazine was very welcomed by the readers.

Soekarno, basically was in favor of the separation between Islam and state and against the idea of a formal-legal relationship between them. Quoted and reformulated the ideas of Halide Edib Hanaoum, Soekarno wrote:

"...religion needs to be liberated from the guidance of the state, in order that it may prosper. If Islam is threatened with lost of influence over the Turkish people that is not because it is not attended by the government, but precisely because it was attended to by the government. The followers of Islam were chained hand and foot to the politics of that government. This was a very big obstacle to the prospering of Islam in Turkey...and not only in Turkey but anywhere... ${ }^{12}$

\footnotetext{
${ }^{10}$ Herbert Feith and Lance Castle, Indonesian Political Thinking, 1945-1965, Ithaca and London: Cornell University Press, 1970, 203.

${ }^{11}$ This article was reprinted in Soekarno's Under the Banner of Revolution, Vol. 1, Jakarta: Publication Committee, 1966, 387-427. My discussion on Soekarno's side on this polemic is mostly based on and referred to this book.

${ }^{12}$ Soekarno, Under the Banner of Revoluion..., 388.
} 
Soekarno also repeated the idea of Mahmud Essad Bey who believes that religion should be separated from the state because under the state or ruling government, religion would be easily misused for political purposes particularly by the kings and authoritarian regime. Thus, in the modern era, separated worldly matter (state) from the spiritual matter (religion) could save the state from disaster and at the same time give an honorable position to religion. In this, Soekarno then cited Kemal Ataturk who says:

I liberated Islam from its bond to the state, so that Islam would not remain a religion just of turning beads (tasbih) in the mosque but would become a movement leading to struggle. ${ }^{13}$

For Soekarno, the purpose of Turki's founding fathers like Ataturk and Bey to separate Islam from state in Turkey was not to disgrace Islamic teaching but conversely to negate and liberate Islam from its obstacles to progress such as authoritarian and narrow-minded ruling government's view on Islam. He says:

"...the freeing of religion from the ties of the state also means the freeing of the state from conservative religious opinions, that is, the freeing of the state from traditional laws and orthodox Muslim concepts which are in fact in conflict with the true spirit of Islam, and which clearly have always been obstacles to the activities of the state leading to progress and modernity. Islam has been separated from the state in order that Islam may become free and that the state too may become free. In order that Islam could develop by itself. In order that Islam may prosper, and that the state too may prosper. ${ }^{14}$

Soekarno further says that this idea of separation between Islam and state was not only implemented in Turkey but also in other countries particularly in the Europe such as Netherlands, Germany, French, Bel-

\footnotetext{
${ }^{13}$ Soekarno, Under the Banner of Revoluion..., 389.

${ }^{14}$ Soekarno, Under the Banner of Revoluion..., 389.
} 
gium, and United Kingdom and also in the United States. To strengthen his argument that Islam and state would be better to be separated, Soekarno also cited the ideas of Muslim scholars which is popularly known in Egypt at that time namely Shaikh Ali Abd al-Raziq ${ }^{15}$ who believes that the argument of integration between Islam and state could not be found in the Quran and Hadith and in the ijma of ulama (consensus among Muslim scholars) because the main duty of the Prophet Muhammad was not to establish Islamic state. Soekarno says:

In 1925, for instance, a book was published in Cairo written by Sheikh Ali Abdul Razik, Al-Islam Wa Usul al Hukm, which set out to show that the work of the prophet was merely to establish just a religion, without any intention of setting up a state, a worldly government, also without any obligation for there to be a caliph or a head of the Muslims to handle state affairs. ${ }^{16}$

In Soekarno's belief, by separating religion from the state, it does not mean that Islamic teachings are automatically marginalized and can not play their role in politics because in a democratic country, Muslim communities can imbue Islamic values into state politics through their representatives in the parliament. Soekarno states:

"...in a country where there is democracy and where there is a people's representative body which truly represents the people, in such a coun-

\footnotetext{
${ }^{15}$ Ali Abd al-Raziq (1888-1966) could be seen as the first Muslim scholar who advocates secularism ideas in Islamic thinking. In his book al-Islam wa 'Usul al-Hukm (Islam and State Principles), published in 1925, a famous and controversial work, Abd al-Raziq asserted that Islam was a religion and not a state, a message not a government, a spiritual edifice not a political institution. For him, the Prophet was only a messenger and not a ruler, that he preached a religion and not a state, and that the caliphate was not a part of Islamic dogmas. Al-Raziq strictly denied the idea that Muhammad had established Islamic state. He believes that the Prophet has never built an Islamic state in Medina. For him, Muhammad's mission was purely Allah's messenger, neither a head of a state nor a political leader. See F. M Najjar, "The debate on Islam and secularism in Egypt", Arab Studies Quarterly, Volume 18, Number 2 (Spring 1996): 1(21).

16 Soekarno, Under the Banner of Revoluion ..., 390.
} 
try the people can nevertheless introduce all kinds of religious elements into any action of the state, into any laws in force in the state, into any political action carried out by the state, even though religion is separated from the state there. Provided only that the politics of the greater part of the members of parliament are Islamic politics, not even a single proposal that is not Islamic in nature will be able to make its way. Are not the Christians in the parliament in Holland for instance, free to pursue Christian politics?. ${ }^{17}$

Soekarno argues that in a democratic country, the state should not officially insert 'a religious state' phrase in its constitution. He disagreed with the idea of a formal-legal relationship between Islam and state in Indonesia in which other religious believes in the multi ethnic and multi cultural country existed. For Soekarno, the idea to make Indonesia as an Islamic state are dangerous for a newly independence Indonesia which will create a sense of discrimination for other non-Muslim communities. In his article 'Saya Kurang Dinamis (I am not Dynamic Enough), Soekarno says:

"...those realities show us that the principle of unity of state and religion for a country whose population is not completely 100 per cent all Islamic, cannot go side by side with democracy. For such a country there are just two alternatives, there are only two things from which one can be chosen: unity of state and religion but without democracy, or democracy, but the state separated from religion. ${ }^{18}$

From the above discussion, it is clear that Soekarno agreed with the idea of secularism which was at that time very popular in the Western countries. For Soekarno, the political secularization that is to separate religion from the state seems to be historically inevitable. Secularism as it was implemented in Turkey, for Soekarno, could have very useful advan-

17 Soekarno, Under the Banner of Revoluion ..., 391.

${ }^{18}$ Soekarno, Under the Banner of Revoluion..., 434 and see also Effendy, Islam and the State ..., 23. 
tages not only for the Turkey as a state but also for Islam as a religion. On the one hand, Islam will not hamper the state to prosper and on the other hand, the state (ruling government) will not misuse Islam for their political purposes.

The ideas of Soekarno above have led to controversial debate among Indonesian political activists during pre-Independence Indonesia. While kebangsaan group supported Soekarno's ideas, Islamic activists disagreed and criticized Soekarno's writings which according to them are very dangerous for the Islamic teachings and Islamic political development in the country. For his opponents, Soekarno was accused to be weak and not comprehensively understood Islamic doctrines and laws because his understanding of Islamic teachings was not directly learnt from Islamic sources written in Arabic; but instead from sources written in English, Dutch, and Germany languages. Soekarno's inability to read Arabic sources was easily found in his letter's correspondent with A. Hasan, entitled Surat-surat Islam dari Endeh (Letters on Islam from Endeh). In his letter Soekarno's says:

This day I finished reading all the books of your composing which I have. I am very anxious to read other works from your pen. And I should also like to read Bukhari and Muslim in Indonesian or English translation? I really need that Bukhari and Muslim since it is there that the hadith are collected which are called authentic. Whilst I have read a statement from an Englishman who knows Islam, that even in Bukhari dubious hadiths have slipped in. He also explains that the decline of Islam, Islam's conservativism, the pollution of Islam, the superstition of the followers of Islam, is largely because of those dubious hadiths which are often more in demand than the verses of the Quran. I think that opinion is correct. ${ }^{19}$

${ }^{19}$ Soekarno, Under the Banner of Revoluion..., 310. 
From the above letter, it is clear that Soekarno admits his weakness in reading Arabic resources. However, it is interesting from this letter to see that Soekarno was in doubt and questioning on the authenticity of Bukhari and Muslim collection which among Muslim are generally perceived to be the most authentic Islamic sources after the Quran. It means that Soekarno has a very progressive and critical thinking of Islamic resources though his information taken from non-Arabian scholars.

Due to their concern with Soekarno's writings which could have 'negative' impacts on the way Indonesian Muslim in general perceived Islam particularly about Islam and state relationship, several Muslim scholars at that time like Ahmad Hassan ${ }^{20}$ and Mohammad Natsir have responded to argue against Soekarno's ideas. Among them, Natsir was the most articulated scholar who can be seen as a representative of Muslim group who oppose the idea of secularism proposed by Soekarno.

\section{Natsir: Islam as a comprehensive way of life}

In response to Soekarno's idea on separation between Islam and state, Natsir wrote several articles which were later compiled as a book chapter entitled Persatuan Agama Dengan Negara. ${ }^{21}$ Natsir argued against Soekarno's idea that Islam should be separated from the state. Natsir believed that Islam is a way of life in which it not only guides Muslim peoples on ritual matter (ibadah) but also on worldly matters (muamalah,

\footnotetext{
${ }^{20}$ Hassan, a leader of Persatuan Islam (Persis) organization wrote series articles entitled Islam dan Kebangsaan. He argued against the idea of Soekarno's nationalism which according to Hassan could lead to ethnic fanaticism (assabiyyah in Arabic). Hassan criticized Soekarno who agrees with the Turkey's and European secularism. Hassan blamed Soekarno for his ignorant of Christian Europe tradition. European tried to separate religion and state in their Christianity doctrine could not found how to rule the state. See Ahmad Hassan, Islam dan Kebangsaan, Bangil: Lajnah Penerbitan Pesantren Persis Bangil, 1984, 101.

${ }^{21}$ This book chapter can be found in Natsir's book Agama dan Negara dalam Perspektif Islam, Jakarta, Media Da'wah, 2001, 75-119.
} 
relation among the Muslims) including how to manage a state. As an ideology, Islam rules all aspects of human life both current life (duniawi) and life after death (ukhrawi). To describe these two duniawi (worldly) and ukhrawi (heavenly) worlds, Natsir in his book Fiqhud Da'wah says:

“...hidup duniawi dan hidup ukhrawi itu pada hakekatnya, hanyalah dua fase (tahapan) dari kehidupan yang satu dan kontinyu; fase yang satu bersambungan dengan yang lain, sebagaimana bersambungannya malam dengan siang, dan siang dengan malam, menurut hokum peredaran angkasa dalam system yang tertentu (worldly and heavenly lives in essence are only two steps from one continued life which are interconnected like interconnection between night and day under the solar system). ${ }^{22}$

Natsir backed up his idea by citing the Quranic verse which says that the Muslim should embrace Islam in total. The Quran says: Hai orangorang yang beriman, masuklah kamu ke dalam Islam secara keseluruhan. ${ }^{23}$ For Natsir, the implication of this Quranic verse means that human being is the servant of Allah (Abdullah) and should follow all Allah commandments. Islam is not only religion that rules the relationship between human being and God (hablum minallah) but also guides the relationship among human beings themselves (hablum minan naas). Thus in the political matter, the Muslim should hold this idea that there is no separation between Islam and state. Natsir rejected the idea of secularism because this idea neglected the transcendental values of Islam and it is dangerous for Muslim life. According to Natsir, a secularist does not have a goal of life after deaths. Natsir says:

Meskipun mungkin pada suatu saat kaum sekularis itu mengakui keberadaan Tuhan, di dalam kehidupan kesehariannya sebagai pribadipribadi sekularis tidak mengakui kebutuhan terhadap suatu hubungan seperti itu dalam kehidupan sehari-hari dinyatakan dalam sikap-sikap,

\footnotetext{
${ }^{22}$ Mohammad Natsir, Fiqhud Da'wah, Malaysia: International Federation of Student Organization, 1981, 12.
} 
tingkah laku dan tindakan-tindakan atau dalam doa ibadah...(although sometimes the secularists people would admit the God existence, in their daily live as a person, they do not admit their needs to have relationship with God as can be seen from their daily acts and worship activities) ${ }^{24}$

For Natsir, the danger of secularism could be seen from the fact that this ideology can not answer the question of what the meaning of life is. He believes that secular persons would easily have a spiritual degeneration. Secularists believe that the concept of God and religion are the product of human creativity, not revealed by God which is not acceptable by Islam.

In his polemic with Soekarno, Natsir argues that the reasons why people like Soekarno does not support his idea on the unity between Islam and state or Islamic state, because they misunderstood on the concept of Islamic state which was commonly portrayed by Western scholars as negative. Natsir says:

Kalau kita terangkan bahwa agama dan negara harus bersatu, maka terbayang sudah di mata seorang bahlul (bloody fool) duduk diatas singgasana, dikelilingi oleh 'haremnya' menonton tari dayang-dayang... Sebab beginilah gambaran pemerintahan Islam yang digambarkan dalam kitab-kitab Eropah yang mereka baca dan diterangkan oleh guru-guru bangsa barat selama ini. Sebab umumnya (kecuali amat sedikit) bagi orang Eropa: Chalifah=harem; Islam=poligami. (If we explained that religion and state should be united, it would be conceived in the eyes of a bloody fool (a secularist people), a seated-king who is surrounded by his ladies in waiting...because that is an image of Islamic state which was described by their books read and taught by their professors in Europe. Because generally for the European: Caliph=ladies in waiting; Islam = polygamy). ${ }^{25}$

\footnotetext{
${ }^{23}$ Quran, 2: 208.

${ }^{24}$ Herbert Feith, The Decline of Constitutional Democracy in Indonesia, Ithaca: Cornel University Press, 1970, 215.

${ }^{25}$ Mohammad Natsir, Capita Selecta, Jakarta: Bulan Bintang, 1973, 436.
} 
According to Natsir, Soekarno perceived the Osmania Empire as an Islamic state but it was not because Turkey under the Osmania Empire according to Natsir was un-Islamic, undemocratic and very authoritarian. Thus, Soekarno's reason that if Islam not separated from the state could lead to authoritarian, and took Osmania Empire as an example, is unacceptable. ${ }^{26}$ Natsir says:

Maka sekarang, kalau ada pemerintahan yang zalim yang bobrok seperti yang ada di Turki di zaman bani Usman itu, bukanlah yang demikian itu, yang kita jadikan contoh bila kita berkata, bahwa agama dan negara harus bersatu. Pemerintahan yang semacam itu tidaklah akan dapat diperbaiki dengan "memisahkan agama" daripadanya seperti dikatakan Ir. Soekarno, sebab memang agama sudah lama terpisah dari negara semacam itu (and now if there is an awful government like Turkey under Osmania Empire, not a such government that we refer to as an example of state that united religion and state. A bad government like that could not be repaired by separating religion from the state as proposed by Soekarno because in fact religion has been separated from such government). ${ }^{27}$

Although Natsir believes in the totality of Islam as a way of life and Indonesian state should be based on Islam, he is not against democracy. Democracy for him is not incompatible with the idea of Islamic state. In fact Natsir believes that Islamic state in its original form to be democratic. Thus, based on this understanding, Natsir developed a new concept of what is called 'Islamic democratic state or Theo-democracy. ${ }^{28} \mathrm{Al}$ though democracy uphold the idea of people's sovereignty which is often contrasted with the God sovereignty in Islam, Natsir does not use this

\footnotetext{
${ }^{26}$ Deliar Noer, The Modernist Muslim Movement in Indonesia, 1900-1942, London; New York: Oxford University Press, 1973, 289.

${ }^{27}$ Natsir, Capita Selecta..., 440.

${ }^{28}$ Luthfi Assyaukanie, "Democracy and the Islamic State: Muslim Arguments for Political Change in Indonesia", The Copenhagen Journal of Asian Studies 20, 2004, 34.
} 
conflicting subject of sovereignty to reject the concept of democracy but to limit it instead. Natsir explains:

"Barangkali orang akan berkata: Bukankah islam itu bersifat demokrasi? Kita jawab: Islam bersifat demokrasi, dalam arti Islam itu anti istibdad, anti absolutism, anti sewenang-wenang. Tidak berarti persetujuan parlemen untuk penghapusan judi dan kecabulan, dan tidak perlu dimusyawarahkan apakah perlu diadakan pemberantasan khurafat dan kemusyrikan atu tidak, dan sebagainya. Bukan! Ini semua bukan hak musyawarah parlemen. ("Perhaps people will ask: Is Islam undemocratic? We answered: Islam is democratic in the sense that it is anti dictatorship (istibdad), anti absolutism and against authoritarianism. [Democracy] does not mean the parliament's approval to abrogate [the legal status of] gambling and pornoghraphy and to whether the myth (khurafat), idolatry (kemusyrikan) and so on, should be discussed democratically. No! this is not the right of Parliament to discuss). ${ }^{29}$

For Natsir, democracy cannot be removed from religious discourse. In fact, its existence must be aimed at serving religion. Democracy which is not guided by religion tends to be secular and thus against Islam. Different with Soekarno's opinion who believes that Turkey under Kemal Ataturk was a democratic states, Natsir argued that it was not. Natsir further stated that under Ataturk, there was only one leader in Turkey whom was called as the Fuhrer or the Duce and there was no freedom of the press, no freedom of thought. Even, according to Natsir, Halida Edib herself who had often been quoted by Soekarno had to flee from Turkey to avoid arrest by the Kemal authoritarian government. ${ }^{30}$

The polemic between Soekarno and Natsir on the relationship between Islam and state and how should Indonesian based on its state ideology have continued prior to and following its independence. In the

\footnotetext{
${ }^{29}$ Mohammad Natsir, Agama dan Negara dalam Perspektif Islam, Jakarta: Media Dakwah, 2001, 89.

30 Deliar Noer, The Modernist Muslim Movement..., 292.
} 
lead up to Indonesian independence, the discourse consisted mainly of an ideological contest about whether Islam or nationalism should form the ideological basis of the new state Indonesia. This debate between kebangsaan group and Islamic group on this issue prior to Independence can be clearly found in their debate on the Jakarta.

\section{Debate on Jakarta Charter (Piagam Jakarta)}

Effendy noted that the serious debate between Islamic and kebangsaan groups prior to the Indonesian independence, was occurred in BPUPKI (Badan Penyelidik Usaha-usaha Persiapan Kemerdekaan Indonesia, Investigatory Committee for Efforts for the Preparation of Indonesian Independence) $)^{31}$ meetings. ${ }^{32}$ BPUPKI was established on 29 April 1945 by the Japanese. In their meetings held from late May to mid-August 1945, the former (Muslim groups) argued that Indonesia should become Islamic state, while the latter (kebangsaan) proposed the creation of a national unitary state in which the affairs of the state should be separated from the affairs of religion (Islam).

To compromise between two conflicting groups, a sub committee consisting of nine members was formed. After serious discussions among the members consists of Soekarno, Mohammad Hatta, A.A. Maramis, Abikusno Tjokrosedjoso, Abdul kahar Muzakkir, H. Agus Salim, Ahmad Soebardjo, A. Wahid Hasjim and Muhammad Yamin, the agreement among them were reached. They agreed that the five principles known

${ }^{31}$ This committee consisted of sixty two members. Out of this number, at most only eleven seemed to represent the Islamic group. They included Ki Bagus Hadikusumo, Abdul Kahar Muzakkir, H. Agus Salim, K.H. Abdul Halim, K.H. Masjkur, H. Ahmad Sanusi, K.H. Mas Mansjur, Abikusno Tjokrosujoso, Sukiman, K.H. A. Wachid Hasjim and A. Baswedan. See Bachtiar Effendy Islam and the State..., 57 and for a complete list of the members see Muhammad Yamin, Naskah Persiapan Undang-Undang Dasar 1945, Vol. 1 Jakarta: Yayasan Prapanca, 1959, 60.

32 Effendy, Islam and the State..., 30. 
as Pancasila would become the Indonesia ideology and appeared in the Preamble of the Indonesian Constitutions. These five principles were the belief in God with the obligation to implement sharia for its adherents; a just and civilized humanity; the unity of Indonesia; a democracy guided by wisdom arising from consultation and representations; and social justice for the whole Indonesian people. Signed by the nine-member committee in Jakarta on 22 June 1945, this draft of Preamble was popularly known as the Jakarta Charter (Piagam Jakarta).

The above agreement among the subcommittee members could be seen as a good compromise between these two opposing groups. On the one hand, the draft accommodated kebangsaan group that Indonesia was not to be Islamic state and on the other hand, the draft recognized Muslims as majority by granting them the right to implement their own law which is clearly stated in the preamble 'dengan kewajiban menjalankan shariat Islam bagi pemeluknya (with the obligation to implement the Islamic sharia for its adherents). ${ }^{33}$ Unfortunately, on 18 August 1945, one day after Indonesian independence, in the meeting of PPKI (Panitia Persiapan Kemerdekaan Indonesia, the Preparatory Committee for Indonesian Independence) headed by Soekarno and Muhammad Hatta, the seven words from the first principle of Pancasila in the Jakarta Charter (dengan kewajiban menjalankan shariat Islam bagi pemeluknya) was omitted. ${ }^{34}$ Since that time, the first principle of Pancasila which was written in the Preamble of Indo-

\footnotetext{
${ }^{33}$ During a discussion in the committee, Wachid Hasjim of Nahdhatul Ulama (NU) had proposed that the adherence to Islam as one of the qualifications to be eligible for the President or the Vice President of Indonesia. This proposal was rejected by the committee. Soekarno at that time argued that since Islam is the majority, the President would obviously be a Muslim without necessarily mentioned this clausal in the constitution. See Muhammad Yamin, Naskah Persiapan Undang-undang Dasar 1945, Vol. 1, Jakarta: Yayasan Prapanca, 1959, 261-263.

${ }^{34}$ According to B. J. Bolan as quoted by Hosen, it was said that a Japanese officer of the Kaigun (Japanese navy) came to Muhammad Hatta to tell him that a Christian representative from Eastern Indonesia objected to the clause of sharia. He was warned that should it
} 
nesian constitution 1945 (Undang-Undang Dasar 1945) was only the Belief in One, Supreme God (Ketuhanan Yang Maha Esa).

Soekarno has convinced the Muslim leaders at that time that this constitution only a temporal one and Muslim could amend the text in the future through constitutional procedure. He says:

"Gentlemen, all of you realize that the Constitution we decide today (18 August 1945) is a temporary constitution. If I may I would like to use the words 'a lighting constitution'. At a later time when the state is in a peaceful and calm situation we would certainly bring together the members of the People's Assembly to make more complete and perfect Constitution. ${ }^{35}$

Soekarno's statement above has made Muslim leaders at that time to believe that when the general elections come the issue could be discussed again. As majority, according to Boland, they believed that their groups would achieve the majority vote which would lead them to insert the seven words omitted constitutionally. ${ }^{36}$ However, there are several Muslim leaders who felt betrayed by this omission. ${ }^{37}$ Isa Anshary for example commented on this omission saying that this event to be tantamount to dishonest politics. ${ }^{38}$ Natsir

be kept unchanged, he and his people (non Muslim from Eastern Indonesia) would separate from the Republic of Indonesia. Hatta was influenced by this message and promised to bring the message to the meeting. See, Hosen, Syariah and Constitutional Reform..., 89.

${ }^{35}$ See Hosen, Syariah and Constitutional Reform..., 91.

${ }^{36}$ B.J. Boland, The Struggle of Islam in Modern Indonesia, The Hague, Martinus Nijhoff, 1982, 37.

${ }^{37}$ The Constitution was convinced by Soekarno as a temporary one could be easily found in Soekarno's speech, saying: "gentlemen, all of you realize that the Constitution we decide today (18 August 1945) is a temporary constitution. If I may I would like to use the words ' a lighting constitution'. At a later time when the state is in a peaceful and calm situation we would certainly bring together the members of the People's Assembly to make more complete and perfect Constitution. See Yamin as quoted by Hosen, Syariah and Constitutional Reform..., 91.

${ }^{38}$ See Endang Saefuddin Anshari, The Jakarta Charter of June 1945: A History of the Gentlemen's Agreement between the Islamic and the Secular Nationalists in Modern Indonesia, M.A. thesis, McGill University, Canada, 1976, 42. 
comments on this omission as a great sacrifice of Muslim to the country for the Indonesian unity. ${ }^{39}$ Agreed with Natsir's argument, Alamsjah describes this moment as 'the greatest gift and sacrifice of the humble Indonesian Muslims as majority population for the sake of Indonesian national unity and integrity..$^{40}$

Since its omission, the missing words of the Piagam Jakarta have never been ended discussed by Muslim politicians through Indonesian political history. In facts Muslim groups have persistently called for re-inclusion of the Piagam Jakarta in the Constitution, ever since those words were dropped in 1945.

\section{Nurcholish Madjid : Islam Yes, Partai Islam, No!}

The efforts of Soeharto regime to marginalize Muslims from politics in his early presidency up to late 1980s have paved the way some Muslim intellectuals to look at an alternative way in their struggle for political Islam to survive. They tried to develop a new format for political Islam in which substance, rather than form, serves as their primary orientations. In regard with the idea of the proper relationship between Islam and state, these intellectuals not only discussed how their political direction and objective should be but most importantly they also re-think their fundamental theological foundation for political Islam to involve in Indonesian politics. Effendy says:

Their agenda requires (1) re-examination of the theological or philosophical underpinnings of political Islam; (2) redefinition of political objectives of Islam; and (3) reassessment of the ways by which those political ideals can be effectively realized..$^{41}$

\footnotetext{
${ }^{39}$ Mohammad Natsir, "Pengorbanan Umat Islam Sangat Besar", Panji Masyarakat, 11 June 1987, 28.

${ }^{40}$ See Pelita (Indonesian daily newspaper), 12 June 1978.

${ }^{41}$ Effendy, Islam and the State..., 66.
} 
These new intellectuals believed that the strategy conveyed by old Muslim generations like Natsir and his proponents as discussed previously, should be reconsidered. They particularly challenged the ideas of previous Muslim political activists who hold an idea that the state is an integral part of Islam or Islam is a way of life (ideology). These new generations have called to rejuvenate of Islamic thought and understanding. They believed that Muslims understandings or interpretations of two main sources of Islam (Quran and Hadith) are subject to change and they urged Muslims to rethink their interpretation of Islam to reconcile with social and contemporary political development in Indonesia. ${ }^{42}$ It is however, important to note that the basic idea of these Muslim intellectuals was not new in Indonesian history because it has been previously expressed by Soekarno in pre-Independence period particularly in his polemic with Natsir.

The ideas of theological renewal and rejuvenation of religious Islamic understanding was cantered around the figures like Nurcholish Madjid (Cak Nur), Abdurrahman Wahid (Gus Dur), Ahmad Syafii Maarif, Djohan Effendy, Ahmad Wahib and M Dawam Rahardjo. Among them, Cak Nur could be seen as the most outspoken figures of these new intellectuals. Thus, elaborating Cak Nur; ideas is important here not only because of his figure as an Indonesian modernist thinkers 'icon' during Soeharto's era and beyond, but also due to his thought's influence which in the later development has inspired other young generations to follow the same path.

The late Nurcholish Madjid, known as Cak Nur, is one of the most influential neo-modernist Islam thinkers in Indonesian history. Born in Mojoanyar, Jombang, East Java on March 17, 1939, he was the rector of

${ }^{42}$ Effendy, Islam and the State..., 69. 
Paramadina University in Jakarta and a professor in Islamic studies at the State Islamic University, (Universitas Islam Negeri) Syarif Hidayatullah, Jakarta. He is known as a prolific writer who has published dozens of books and hundred of articles in various academic journals. He obtained his $\mathrm{PhD}$ degree in philosophy from the University of Chicago with his thesis entitled, "Ibnu Taimiya on Kalam and Falsafah: Problems on Reasons and Revelation in Islam" under supervision of Fazlur Rahman. His elementary to high school education was in traditional Islamic boarding schools. He went to his father's religious school al-Wathoniyah madrasah for elementary education and continued his at the Darul Ulum pesantren in Rejoso, Jombang. His high school education was in the Pondok Modern Darussalam (modern Islamic boarding School) in Gontor, where he completed his Islamic education in 1960. Then, he moved to Jakarta and enrolled in the Faculty of Islamic Literature and Culture at the State Institute for Islamic Studies (IAIN) Syarif Hidayatullah where he obtained his bachelor degree in Arabic Literature in 1968.

The young Nurcholish Madjid was an Islamic activist. While he was studying at IAIN, he was elected as the general chairman of Himpunan Mahasiswa Islam (HMI) or Islamic Student Association, for two consecutive periods, 1966-1969 and 1969-1971. He was the only chairman who holds this position for more than one period in this organization's history; although he often said that it was a historical accident that made him hold the chairmanship for two periods.

His intellectual reputation soared in the public eye following his controversial speech on January 2, 1970, entitled Keharusan Pembaharuan Pemikiran Islam dan Masalah Integrasi Ummat (The Necessity of Renewing Islamic Thought and the Problem of the Integration of the Ummah). This speech was controversial because Madjid argued for the need for a liberalization process in the teachings and views of Islam. For Madjid, the 
liberalization of outlook towards the present teachings of Islam in Indonesia should involve secularization, intellectual freedom and the idea of progress and open attitudes. In his account, that process is needed to allow renewal of Islam so it can free "[itself] from traditional values" and "seek values which are oriented toward the future". ${ }^{43}$ Madjid offered the straightforward observation that Indonesian Muslims suffered stagnation in religious thinking and had lost the "psychological striking force" in their struggle. ${ }^{44}$ An important indication of this intellectually disarticulated Indonesian Muslim, as observed by Madjid, was the inability of the vast majority of Muslims to differentiate values which were transcendental from those which were temporal. In fact, he pointed out further that the hierarchy of values was often the reverse; transcendental values were conceived as temporal and vice versa. Everything was likely to be perceived as transcendental, and therefore, without exception, valued as divine. As a result of this mode of religiosity, "Islam is [viewed as] equal in value and traditions; and becoming Islamic is comparable to being traditionalist". ${ }^{45}$

In his paper, moreover, Madjid wrapped his ideas in a highly controversial jargon, that is, sekularisasi (secularization). The controversy over his speech forced him to write Beberapa Catatan Sekitar Masalah Pembaharuan Pemikiran dalam Islam (Some Notes on Renewing Islamic Thought) and Sekali Lagi tentang Sekularisasi (One more Time about Secularization) in $1972 .{ }^{46}$ In both writings, he clarified his position on secular-

\footnotetext{
${ }^{43}$ Nurcholish Madjid. "The Necessity of Renewing Islamic Thought and the Problem of the Integration of the Ummah", in Charles Kurzman, (ed.), Liberal Islam: A Source Book, New York: Oxford University Press, 1998, 286. See also Nurcholish Madjid. The True Face of Islam: Essays on Islam and Modernity in Indonesia, Jakarta: Voice Center Indonesia, 2003, 317.

${ }^{44}$ Madjid, The True Face of Islam..., 287.

${ }^{45}$ Madjid, The True Face of Islam..., 288.

${ }^{46}$ These two essays are included in Majid's book Islam Kemoderenan dan Keindonesiaan, Bandung: Mizan, 1987, 215-256.
} 
ization, which had been attacked by many Indonesian Muslim scholars who argued that secularization without secularism is impossible. In defending his position, Madjid first elaborated upon the etymology of the word "secular" and its neutral meaning. He firmly believed that secularization is possible and an obligation of all religious human being, especially Muslims, as this is in accordance with the teaching of Islam. Madjid argued that secularization is inevitably a realization of the primary Islamic oath (syahadat) which states that there is no God but Allah and Muhammad is His Prophet. By professing that there is no God but Allah, Muslims must be critical of all Islamic interpretations in order to avoid absolutism, because the only absolute thing is God.

As indicated in his paper, his concept of 'sekularisasi' was borrowed from Harvey Cox, a respected American theologian who maintains that secularization is different from secularism. Cox defines secularization as "the liberation of man from religious and metaphysical tutelage, the turning of his attention away from other worlds and toward this one". ${ }^{47}$ Thus, according to Effendy, it was the notion of "liberating development" as well as the "clear distinction between secularization and secularism" which Madjid employed in articulating his ideas concerning the logical consequences of Islamic monotheism (al-tawhid). ${ }^{48}$ This can be seen from notes that Madjid he put in his paper:

Secularization does not mean the application of secularism, because "secularism is the name for an ideology, a new closed world view which functions very much like a new religion". What is meant here is any form of "liberating development"...Thus, "secularization" does not mean to apply secularism or to transform Muslim into secularist. What

\footnotetext{
${ }^{47}$ Harvey Cox. The Secular City: Secularization and Urbanization in Theological Perspective, New York: Macmillan Company, 1966, 17.

${ }^{48}$ Effendy, Islam and the State..., 73.
} 
is intended is to "temporalize values, which are in fact temporal, and to free Muslims from the tendency to spiritualize these values. ${ }^{49}$

With his statement above, Madjid not only provided an explanation what he meant by secularization, but at the same time he also reconfirmed his position opposing the notion of "secularism". The term "secularization" was meant as necessary process that would enable the Islamic community to distinguish between transcendental and temporal values. For Madjid, 'secularization" understood as process of liberating development, is also a conditio sine qua non to facilitate Muslims, in accordance with their function as vicegerents of God (khalifat al-Allah fi al-ardh) in their endeavors to relate the universalism of Islam to today's Indonesia. ${ }^{50}$

Although Madjid still remained faithful to the substance of his renewal ideas, after he obtained his $\mathrm{PhD}$ from Chicago in 1980s, he no longer employs the controversial term "secularization”. Instead, Madjid has been able to smoothly rephrase the term "secularization" as "radical devaluation" or "desacralization". This change, Effendy notes, could be inspired by indirect intellectual encouragement of similar understanding of "secularization" that is promoted by influential sociologists such as Talcott Parsons and Robert N. Bellah. ${ }^{51}$ Madjid believes that there is nothing sacred about the matters of an Islamic state, Islamic political parties, or Islamic ideology. Accordingly, Muslim should be able to "secularize" or "desacralize" their perceptions on those worldly issues. In the light of this, he introduced the phrase: "Islam Yes, Partai Islam No" (Islam Yes, Islamic Party, No!). With this jargon, among other things, he encouraged his fellow Muslims to direct their commitment to Islamic values and not to institutions, even those of Islamic origin such as Islamic parties.

\footnotetext{
${ }^{49}$ Madjid, The True Face of Islam..., 317.

${ }^{50}$ Effendy, Islam and the State..., 73.

${ }^{51}$ Effendy, Islam and the State..., 73.
} 
If Islamic organizations represent the vehicles for Islamic ideas, according to Barton, why is it, Madjid asked that people are not attracted to Islamic organizations. ${ }^{52}$ The reasons, Madjid argues, are obvious that Islamic organizations are no longer attracting the kind of mass support that they once did. This support declined because the nature of the thought that these organizations represent and disseminate has become stale; and it was also caused by the fact that Islamic parties and their leaders have lost credibility in the eyes of the public. Madjid says:

The answer to the above question can be found by asking the following question: to what extent are they attracted to Islamic parties and organizations? Except a few, it is obvious that they are not attracted to Islamic parties or organizations. Thus, their attitudes might more or less be expressed through the saying: "Islam, Yes; Islamic Party, No!". If Islamic parties are regarded as the vessels of ideas, which are going to be fought for on the basis of Islam, then these ideas are now obviously unappealing. ${ }^{53}$

Madjid's search for a contextual Indonesian Islamic theology draws upon his understanding of what he calls the underlying "spirit" of Islam. Like other Muslim liberals, he makes a distinction between the "spirit" and the "textual" of religious traditions insisting that the former must be given primacy over the latter. He sees this new perspective as emanating from the process of ijtihad which he defines as "a method of rational and realistic interpretation of Islam" based on the principles of "public interest". ${ }^{54}$ If equality and social justice are cardinal pillars of Islam, then, he says, developing new way of imaging Islamic law through ijtihad are required in order to realize core Islamic values in today's context; although this does not mean that tradition must be wholly jettisoned.

\footnotetext{
${ }^{52}$ Barton, Greg. Gus Dur: The Authorized Biography of Abdurrahman Wahid, Jakarta: Equinox Publishing, 2002, 124..

${ }^{53}$ Madjid, The True Face of Islam..., 316.

${ }^{54}$ Madjid, The True Face of Islam..., 60.
} 
Madjid continued working on renewal Islamic thought in Indonesia until his departure on August 29, 2005 which was considered by Indonesian, particularly Muslim, as a great lost of "bapak bangsa" or the father of nation. In his article following Madjid's departure, Barton says:

Indonesia, home to some of the most significant progressive Islamic ideas in the modern period has lost one of its greatest thinkers just when he was needed most. The untimely death last week of Nurcholish Madjid (66), a leading advocate for a tolerant and peaceful understanding of Islam, after a long struggle with Hepatitis, has been noted not only across Indonesia, where he was given a state funeral, but also around the world. ${ }^{55}$

Madjid's ideas and struggles in renewing Islamic thought in Indonesia have influenced young Indonesian Muslims to follow his step. His legacy and influence can be seen in his many young liberal and progressive Muslim intellectual cadres in Indonesia. According to Bruinessen, the role of provocative, innovative and liberating thinker and broker of ideas that he played for his own generation is now played by a highly varied group of younger men and women, in various institutions, NGOs and informal networks in Indonesia. ${ }^{56}$

\section{Concluding Remarks}

From the lengthy discussion presented above, it is safe to argue that Muslims both individuals and institutions have actively involved in the struggle for democracy in Indonesia since early Indonesian state establishment up to present. Their struggle for democracy has been colored by the resentment between political Islam and the state which was largely due to Muslims formalistic quest for Indonesian Islamic state on the one

\footnotetext{
${ }^{55}$ Greg Barton, "Peaceful Islam and Nurcholish's Lasting Legacy, the Jakarta Post, September 6, 2005.

${ }^{56}$ Martin van Bruinessen. "Nurcholish Madjid: Indonesian Muslim Intellectual, in ISIM Review 17 (Spring 2006), 23.
} 
hand as proposed by Natsir and state's conceptualization of a nationalunitary construct of state with Pancasila as its ideology as suggested by Soekarno.

This antagonism above, however, has been changed when the new Muslims intellectuals promoted their struggle to more focus on substance rather than the form as their predecessors requested as can be seen from the view of Madjid. And after the Soeharto's out of offices, the tendency of several Muslim radical groups have tried to return back to their formalistic inquiry such as inclusion of Islamic sharia into Indonesian constitution which was finally responded by young Muslim generations post-Madjid.

Madjid's search for a contextual Indonesian Islamic theology draws upon his understanding of what he calls the underlying "spirit" of Islam. Like other Muslim liberals, he makes a distinction between the "spirit" and the "textual" of religious traditions insisting that the former must be given primacy over the latter.

Madjid seems to propose the middle path between Soekarno and Natsir in his struggle to 'Islamize' Indonesia. On the one hand, Madjid opposes the idea of making Indonesia an Islamic state, consistently arguing that if Islam is instituzionalized in the state, it will go against the plurality of Indonesian society and will marginalize many minorities which would lead inevitably to national disintegration. On the other hand, Madjid also refuses that Indonesian become totally a secular state. Madjid's new perspective has been emanated from the process of ijtihad which he defines as "a method of rational and realistic interpretation of Islam" based on the principles of "public interest" ${ }^{57}$

Finally, the debate among the Indonesian leading figures above is important due to its style and impact on the Muslim communities at that

\footnotetext{
${ }^{57}$ Bruinessen. "Nurcholish Madjid”..., 60.
} 
time. On the one hand, although these three figures have a very sharp different opinion on the issue, they debate the issue politely and in a democratic way. Natsir for example did not label Soekarno as murtad (apostasy) or kafir (infidel) even though Soekarno did not agree with his idea of Islamic state. On the other hand, the polemic had contributed to the awareness among Muslim communities at that time that Islam not only manage and related to theology and hereafter (akhirat) issues but also Islam concerns with individual, social, culture and state issues. It is also important to note here that the discourse of democratization in Indonesia could become the place for the Muslim, who rejected the ideas of integration between religion and state, to play their role. And at the same time, in its democracy discourse, Islam would still have a public arena to develop dynamically in the name of Indonesian democratization process.

\section{Bibliography}

Anderson, Benedict R. O'G. Java in a time of revolution: occupation and resistance, 1944-1946. Ithaca: Cornell University Press, 1972.

Anshari, Endang Saefuddin. "The Jakarta Charter of June 1945: A History of the Gentlemen's Agreement between the Islamic and the Secular Nationalists in Modern Indonesia," M.A. thesis, McGill University, Canada, 1976.

Anwar, M. Syafi'i. "Shari'a, Pluralism and the Prospect of democracy in Post Soeharto Indonesia", paper presented at EU-Indonesia Day Conference on Pluralism and Democracy: Indonesian Perspective, Brussels, 7 December, 2006. Assyaukanie, Luthfi. "Democracy and the Islamic State: Muslim Arguments for Political Change in Indonesia", The Copenhagen Journal of Asian Studies 20 (2004).

Barton, Greg. Gus Dur: The Authorized Biography of Abdurrahman Wahid. Jakarta: Equinox Publishing, 2002.

Barton, Greg. "Peaceful Islam and Nurcholish's Lasting Legacy", the Jakarta Post, September 6, 2005. 
Boland, B. J. The Struggle of Islam in Modern Indonesia. The Hague: Martinus Nijhoff, 1982.

Bruinessen, Martin van. "Nurcholish Madjid: Indonesian Muslim Intellectual", ISIM Review 17 (Spring 2006).

Cox, Harvey. The Secular City: Secularization and Urbanization in Theological Perspective, New York: Macmillan Company, 1966.

Effendy, Bahtiar. Islam and the State in Indonesia. Singapore: Institute of Southeast Asian Studies, 2003.

Feith, Herbert. The Decline of Constitutional Democracy in Indonesia. Ithaca: Cornel University Press, 1970.

Feith, Herbert and Lance Castle. Indonesian Political Thinking, 1945-1965. Ithaca and London: Cornell University Press, 1970.

Hosen, Nadirsyah. "Syariah and Constitutional Reform in Indonesia (1999. 2002)", PhD thesis at National University of Singapore, 2005.

Madjid, Nurcholish. Islam Doktrin dan Peradaban: Sebuah Telaah Kritis tentang Masalah Keimanan, Kemanusiaan, dan Kemodernan. Jakarta: Yayasan Wakaf Paramadina, 1992.

Madjid, Nurcholish. Islam, Kemodernan, dan Keindonesiaan. cet. V. Bandung: Mizan, 1993.

Madjid, Nurcholish. Islam, Kerakyatan dan Keindonesiaan: Pikiran-pikiran Nurcholish 'Muda'. Bandung: Mizan, 1993.

Madjid, Nurcholish. Islam Agama Kemanusiaan, Membangun Tradisi dan Visi Baru Islam Indonesia. Jakarta: Yayasan Wakaf Paramadina, 1995.

Madjid, Nurcholish. Islam Agama Kemanusiaan: Membangun Tradisi dan Visi Baru Islam Indonesia. Jakarta: Paramadina, 1995.

Madjid, Nurcholish. Islam Agama Peradaban: Membangun Makna dan Relevansi Doktrin Islam dalam Sejarah. Jakarta: Paramadina, 1995.

Madjid, Nurcholish. Pintu-Pintu Menuju Tuhan. Jakarta: Paramadina, 1996.

Madjid, Nurcholish. Masyarakat Religius. Jakarta: Paramadina, 1997.

Madjid, Nurcholish. Tradisi Islam: Peran dan Fungsinya dalam Pembangunan di Indonesia. Jakarta: Paramadina, 1997.

Madjid, Nurcholish. Dialog Keterbukaan: Artikulasi Nilai Islam dalam Wacana Sosial Politik Kontemporer. editor: Edy A. Effendi, Jakarta: Paramadina, 1998.

Madjid, Nurcholish. Integration of the Ummah", in Charles Kurzman, (ed.). Liberal Islam: A Source Book. New York: Oxford University Press, 1998.

Madjid, Nurcholish. Cita-Cita Politik Islam era Reformasi. Jakarta: Paramadina, 1999.

Madjid, Nurcholish. Indonesia Kita. Jakarta: Univeritas Paramadina, 2003. 
IJIMS, Indonesian Journal of Islam and Muslim Societies, Volume 6, Number 1, June 2016: 63-92

Najjar, F. M. "The debate on Islam and secularism in Egypt", Arab Studies Quarterly, Volume 18, Number 2 (Spring 1996).

Natsir, Mohammad. Capita Selecta. Jakarta: Bulan Bintang, 1973.

Natsir, Mohammad. Fiqhud Da'wah. Malaysia: International Federation of Student Organization, 1981.

Natsir, Mohammad. "Pengorbanan Umat Islam Sangat Besar", Panji Masyarakat, 11 June 1987.

Natsir, Mohammad. Agama dan Negara dalam Perspektif Islam. Jakarta: Media Dakwah, 2001.

Noer, Deliar. The Modernist Muslim Movement in Indonesia 1900-1942. London: New York: Oxford University Press, 1973.

Sukma, Rizal. Islam in Indonesian Foreign Policy. New York: Routledge Curzon, 2003.

Yamin, Muhammad. Naskah Persiapan Undang-Undang Dasar 1945, Vol. 1. Jakarta: Yayasan Prapanca, 1959. 